拡散接合による微細噴流穴付き放電加工総形電極の製作

柴山智幸* 国枝正典*

\title{
Diffusion-bonded tool electrode for electrical discharge machining with microchannels for jetting dielectric liquid
}

\author{
Tomoyuki SHIBAYAMA and Masanori KUNIEDA
}

\begin{abstract}
In this paper, we describe the improvement of the machining characteristics of sinking electrical discharge machining (EDM) using a tool electrode that has microholes for jetting dielectric liquid over the working surface. The tool electrode was made by diffusion bonding copper plates, on the surface of which microgrooves for jetting the dielectric fluid were formed by electrolyte jet machining. The bonded tool electrode was finished by turning to obtain a hemispherical shape. When dielectric liquid was dripped from the microholes over the tool electrode surface, processing time was shortened and machining stability and accuracy were improved compared with the case of the conventional solid tool electrode.
\end{abstract}

Keywords: electrical discharge machining, tool electrode, diffusion bonding

\section{1. はじめに}

油中形彫り放電加工においては, 安定した加工 を行うために加工液供給による加工屑排出と極間 および工具電極の泠却が重要である。一般に加工 液供給の方法としては, 工具電極の昇降動作（ジ ヤンプ動作）により生じるポンプ作用によるもの や，工具電極に設けた穴から加工液を噴流する方 法が挙げられる。しかし, 前者ではジャンプ動作 中は放電が生じないため加工が進行しないので加 工速度が低下寸る。また，後者では噴流穴をドリ ルで加工するため工具電極の形状や大きさに制限 が生じる。そこで，筆者ら 1)はこれらの問題を解 決するため, 拡散接合により微細加工液流路を形 成した放電加工用電極を開発した. Fig.1 に示すよ うに，まず銅板上に機械加工により幅が広く深い 導入路を形成し, その先に電解液ジェット加工 2) を用いて幅と深さが数十ミクロンの微細溝パター ンを形成する (Fig.1a).この銅板を平らな銅板と 重初て拡散接合により一体化する (Fig.1b)。こう して得られた工具電極素材を目的の形状にワイヤ 放電加工, または切削を利用して形状成形し (Fig.1c), 放電加工用の工具電極を製作寸る。こ

* 東京農工大学大学院機械システム工学専攻 （東京都小金井市中町 2-24-16）
れより放電加工中に加工屑が排出されにくい箇所 などに加工液を浸み出させることができるので, ジャンプ動作を行うことなく加工屑排出ができる (Fig.1d). 特に深溝加工のようにアスペクト比の 大きい加工の場合は，工具電極の断面積が小さい ので, ジャンプによるフラッシング効果が十分で ない. そこで，この原理に基づいて深溝用電極を 製作し, 微量な加工液を供給しながら加工を行っ た。 その結果, 従来のジャンプ動作による加工法 より加工速度が向上し, 加工精度も同等であるこ とや, 加工液の流量は $1 \mathrm{ml} / \mathrm{min}$ 程度で十分である

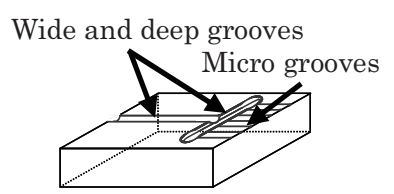

(a) Fabrication of micro grooves

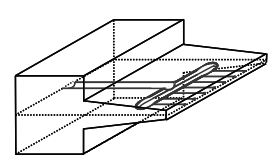

(c) Contouring by WEDM

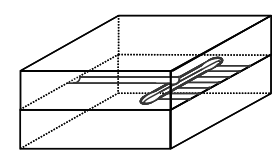

(b) Diffusion bonding

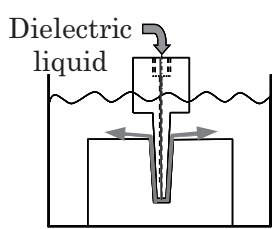

(d) Sinking EDM
Fig.1 Manufacturing tool electrode with micro channels for deep slot machining 
ことが報告されている 1 )。一方，放電加工用の工 具電極は無垢の電極素材を切削またはワイヤ放電 加工などにより任意の形状に成形される。 その形 状は深溝加工用のみならず, 複雑曲面や大面積を 有するものなど多岐にわたる，そこで，本研究で は薄板を多数枚積層し拡散接合することで, 微細 流路を形成した任意形状の総形電極が製作可能な 工具電極素材の開発を試みた。

\section{2. 切削により微細噴流穴を閉塞させた深溝加エ 電極による加工特性 \\ 2. 1 目的}

前報 1)において，微細噴流穴を設けた工具電極 素材から所望の工具電極形状を加工する場合は, 熱加工であるワイヤ放電加工を用いた。これは, 切削で加工すると, 材料の塑性流動により微細噴 流穴が閉塞してしまうためである。しかし，一般 の総形電極製作においては, 自由曲面が加工可能 な切削を用いる場合が多い，そこで本節では，総 形電極製作のための基礎実験として, 工具電極を 切削により加工し, 表面の微細噴流穴の開口状態 を調べた。また，切削後は閉塞状態にあっても， 工具電極の消耗により閉塞状態が解消されること が期待できる. 特に加工初期は加工深さが浅いた め, 加工屑の排出も容易であり加工が不安定にな ることは少ないので, 加工深さが深くなってから 開口部が形成されれば十分であると考えられる.

\section{2 実験方法}

Fig.1 と同様に二枚の銅板を拡散接合して工具 電極先端部に微細噴流穴 (開口部の寸法 $200 \mu \mathrm{m} \times$ $80 \mu \mathrm{m})$ を 8 個設けた深溝加工用電極を製作した. 銅板上に電解液ジェット加工で微細溝を形成する 時の条件は, ノズル内径 $0.1 \mathrm{~mm}$, 加工電流 $10 \mathrm{~mA}$, ノズル送り速度 $0.15 \mathrm{~mm} / \mathrm{s}$ であり, 各々の溝は 3 回のノズル走査で形成した。 そして, 拡散接合後 に工具電極表面を切削により加工し, 意図的に噴 流穴を閉塞させた。この工具電極を用いて Table 1aに示す荒加工条件により深溝加工を試み, 噴流

Table 1 Machining conditions

\begin{tabular}{l||c|c}
\hline \multicolumn{1}{c||}{ Roughing conditions } & $\mathrm{a}$ & $\mathrm{b}$ \\
\hline \hline Discharge duration $[\mu \mathrm{s}]$ & 650 & 210 \\
\hline Discharge interval $[\mu \mathrm{s}]$ & \multicolumn{2}{|c}{50} \\
\hline Discharge current $[\mathrm{A}]$ & 50 & 40 \\
\hline Discharge voltage $[\mathrm{V}]$ & \multicolumn{2}{|c}{120} \\
\hline Servo voltage [V] & \multicolumn{2}{|c}{40} \\
\hline \multicolumn{1}{||c}{ Polarity } & \multicolumn{2}{|c}{ Workpiece(-) } \\
\hline
\end{tabular}

ポンプの圧力を一定としたときの加工深さ毎の加 工液噴流流量と加工速度を調查した。使用した放 電加工機は株式会社ソディック製 $\mathrm{AQ} 35 \mathrm{~L}$ である.

\section{3 実験結果}

Fig.2 に加工開始から終了までの加工深さ（0, 1, $2,10,20,30 \mathrm{~mm}$ ) と加工液流量の関係を示す. 加 工前は噴流口は完全に閉塞されていた。加工液は 深さ $2 \mathrm{~mm}$ のあたりから供給され始めており，そ の後は加工深さの進展に伴い流量が増加している のがわかる。これより, 深さ $2 \mathrm{~mm}$ 付近に達した あたりから工具電極の消耗により噴流穴の閉塞状 態が解消し, 加工液が供給され始めたと考えられ る.また, 流量が増加しているのは, 消耗の進行 に伴って開口した穴の数と開口径が大きくなるこ とと, 放電の熱により工具電極の温度が上昇し, 加工液の粘性が低下したためと考えられる.

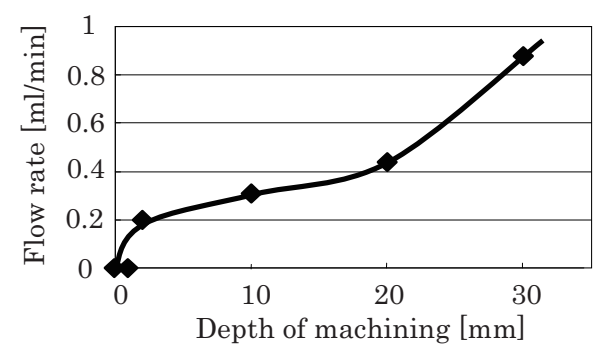

Fig.2 Increase in flow rate with increasing depth of machining and opening of clogged micro channels

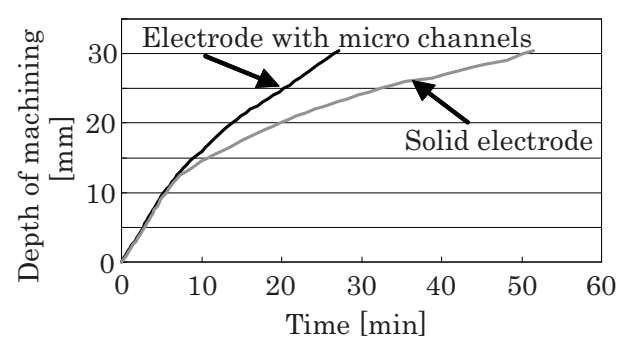

Fig.3 Material removal rate in deep slot machining

Fig.3 に加工時間と加工深さの関係を示す.噴流 穴を持たない中実の工具電極による加工結果も併 せて示寸．噴流穴から加工液を供給しながら加工 を行うことで, 加工屑排出を行わない場合に比べ, 加工速度が約 2 倍に向上しているのがわかる。こ れは, 加工液により加工屑が速やかに排出され, 加工屑排出を行わない場合に比べ短絡が減り, 安 定した加工がなされたためであると考えられる. 特に, 加工深さが深いときにその効果が大きい. この結果より，切削により工具電極成形を行い噴 
流穴が閉塞した場合でも，消耗に伴い開口し加工 液の供給が可能であることがわかった。

\section{3. 半球状電極を用いた放電加工特性}

\section{1 工具電極製作工程}

工具電極素材からどのような工具電極形状に 加工しても表面上に噴流穴が均一に分布するよう な流路配置を施す必要がある。そこで板厚 $2 \mathrm{~mm}$ の銅板一枚ごとに Fig.4a に示すように加工液導入 用の貫通穴をドリル加工し, 電解液ジェット加工 2)によりその穴の中心から $5^{\circ}$ の間隔で Fig.4a の 扇形の領域のみに放射状に微細溝を形成した。微 細溝の断面を Fig.5 に示す. 放電条件には荒加工条 件を用いるため, 放電ギャップが広く，この程度

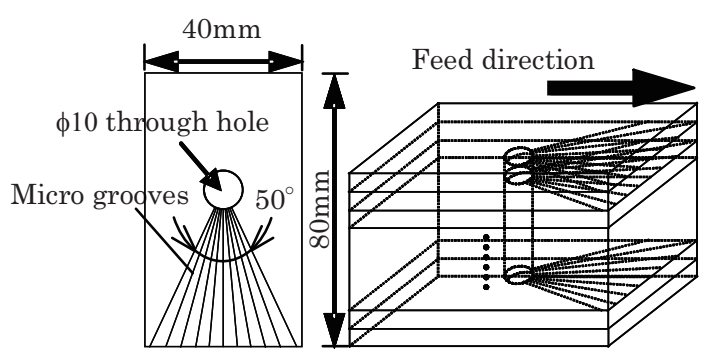

(a) Fabrication of micro grooves (b) Diffusion bonding

Fig.4 Manufacturing tool electrode for sinking EDM of 3D shapes

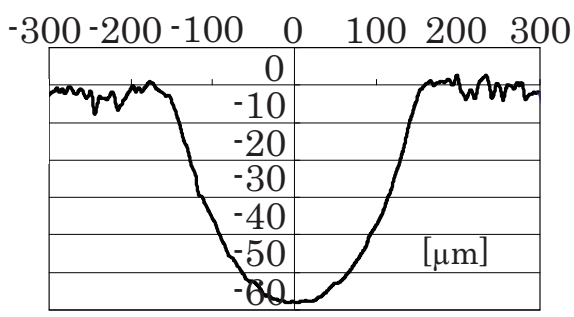

Fig.5 Cross section shape of micro groove machined by electrolyte jet machining (Nozzle diameter: $0.1 \mathrm{~mm}$, machining current: $10 \mathrm{~mA}$, nozzle feed speed: $0.15 \mathrm{~mm} / \mathrm{s}$, scanning: two times)

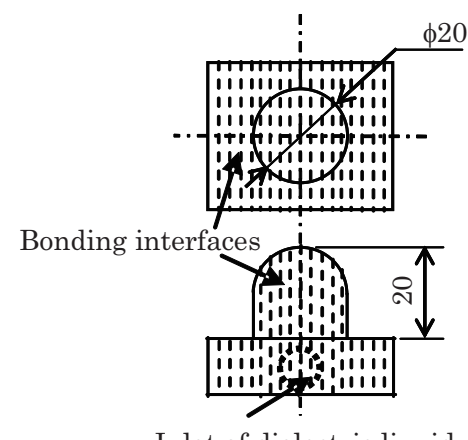

Fig.6 Hemispherical tool electrode machined by turning
の開口の噴流穴の転写は無視できると考えられる. Fig.4aの流路を片面に形成した銅板を 12 枚積層 し，さらにそれを流路のない平らな銅板 2 枚の間 に挟み，計 14 枚を，拡散接合により一体化した

(Fig.4b)．こうして得られた総形電極素材を積層 面が放電加工時の工具電極送り方向と平行となる ように NC 旋盤を用いて Fig.6 の形状に加工した.

\section{2 放電加工条件}

実験には Table 1b に示寸荒加工条件を用いた. そして, 以下の三種類の加工屑排出手段について 比較を行った。1)拡散接合により噴流穴を設けた 半球状電極を用いて，ジャンプ動作をさせること なく, 微細噴流穴から加工液を供給する方法. 2) 中実の半球状電極を用いて, Table 2 に示す高速ジ ヤンプ動作でフラッシングを行う方法．3）中実の 半球状電極を用いて，ジャンプ動作もさせず，加 工液の供給も行わないで加工寸る方法である.

Table 2 Jump flushing motion of tool electrode

\begin{tabular}{l|c}
\hline Jump velocity $[\mathrm{m} / \mathrm{s}]$ & 0.6 \\
\hline Period $[\mathrm{s}]$ & 0.36 \\
\hline Height $[\mathrm{mm}]$ & 2 \\
\hline
\end{tabular}

\section{3 加工速度}

各条件での加工時間と加工深さの関係を Fig.7 に示す．中実電極であってもジャンプ動作を行い ながら加工を行うと, 安定した加工が行えた。し かし，加工速度は最も遅い。噴流をせずにジャン プ動作も行わずに加工した場合は，加工深さが浅 い時は加工速度が早い。しかし，加工深さ $10 \mathrm{~mm}$ のあたりで加工速度が低下し始め，目標深さであ

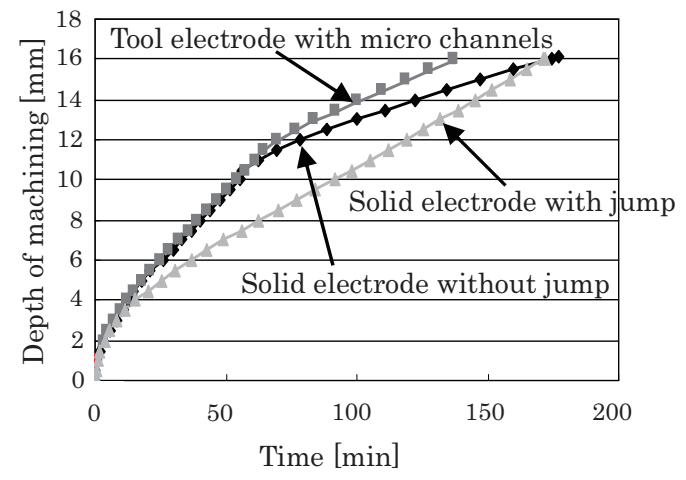

Fig.7 Machining speed 
る $16 \mathrm{~mm}$ に達するには, ジャンプ動作による加工 より長い時間を必要とした。微細噴流穴を形成し た電極を用いて加工を行った場合は，加工の初期 段階では加工速度が噴流なしの場合と等しい。こ れは，最初は噴流穴が閉塞していて加工液が供給 されていないからである.深さ $12 \mathrm{~mm}$ を越えたあ たりからは加工液の供給による加工屃排出の効果 が出始め, 最終的に最も短時間で目標深さまで達 している. ここで, 加工深さ $2 \mathrm{~mm}$ ごとの加工液 の供給流量を測定した結果を Fig.8 に示寸. 加工の 進行とともに流量は増え, 約 $0.15 \mathrm{ml} / \mathrm{min}$ に収束 している。これは, 深さ $10 \mathrm{~mm}$ までは, 加工の進 行に伴い噴流口の数が増えていくため, 流量が増 加していると考えられ, $10 \mathrm{~mm}$ 以降は噴流口数が 増えないため流量が一定になったと考えられる.

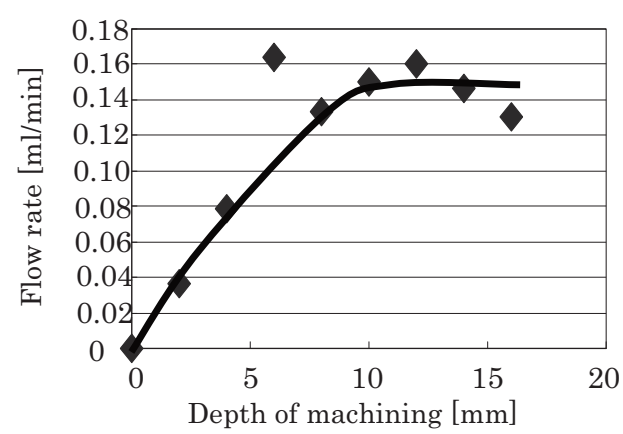

Fig.8 Change in flow rate of dielectric liquid with increasing depth of machining

一方で, 加工深さ $12 \mathrm{~mm}$ 以降の微細噴流穴付電 極の場合とジャンプ動作による加工速度を比較す ると, ジャンプ動作による加工の方が, 微細噴流 穴付電極を用いた加工よりも大きい. Fig. 8 に示 寸程度のわずかな流量でも十分に加工は安定する が, ジャンプ動作で得られる場合以上のフラッシ ング効果を得るにはもう少し流量が必要であるこ とがわかる。

\section{4 加工精度}

加工後の工具電極と工作物を表面形状測定機 で測定した. 工具電極は球の頂点を通過するよう に中心角 $\pm 26^{\circ}$ の間を測定した．また，工具電極 の根元部の径はマイクロメータにより測定した. 拡散接合により製作した工具電極に関しては，接 合面に対して平行に表面形状測定した。 工作物の 底形状については，工具電極と対応する箇所を表 面形状測定機により測定し, 加工穴の入口径は測 定顕微鏡により測定した。そして，底面ギャップ

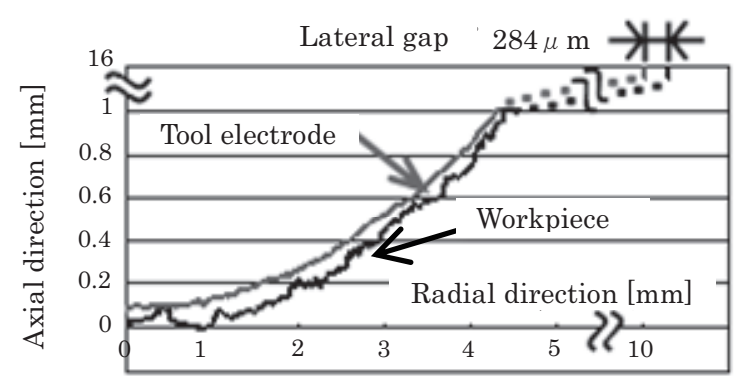

(a) Solid electrode with jump

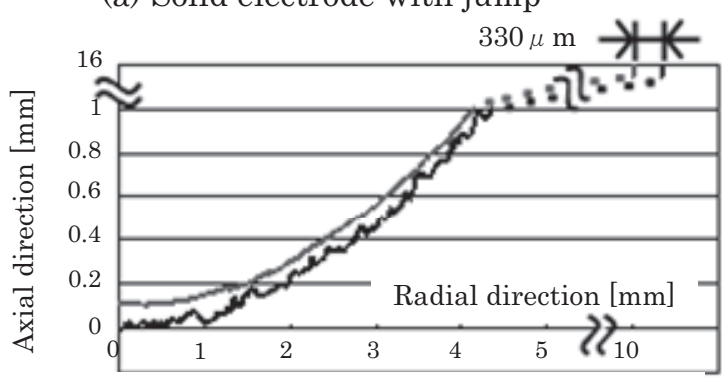

(b) Tool electrode with micro channels

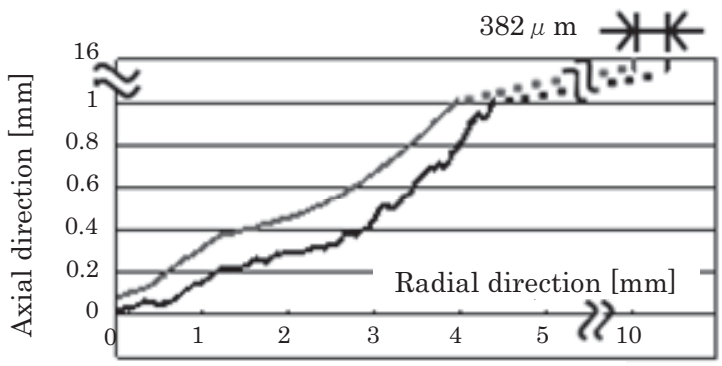

(c) Solid electrode without jump

Fig.9 Measured shapes of tool electrode and workpiece

を考慮した上で工具電極形状と工作物形状の位置 合わせを行った結果を Fig.9 に示す。これより, ジ ヤンプも噴流も行わずに加工した場合に，最もギ ヤップが広く, 転写精度が悪いことがわかる。一 方でジャンプ加工では，ギャップが狭く精度のよ い加工が行われている。また, 微細噴流穴から加 工液を供給した場合も，噴流なしに比べ狭くて均 一なギャップで加工されており，ジャンプによる 加工に匹敵する精度で加工されているのがわかる. 一方で，製作した微細噴流口付電極には Fig.10に

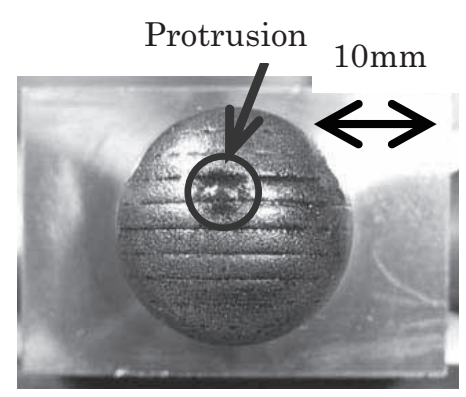

Fig.10 Tool electrode after EDM 
示すように接合境界に沿って異常消耗が生じ，溝 が形成されているのが確認できた。 それに対応し て Fig.11 に示寸工作物の加工面には工具電極の溝 が転写されているのが分かる。また, 微細噴流口 付電極には Fig.10のように突起が頂点部に形成

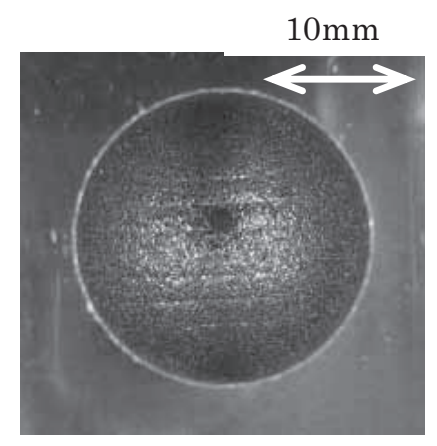

Fig.11 Bottom surface of machined cavity

されていた。これは加工液流量が少なく、ジャン プ動作による加工に比べて加工屑の排出効率が悪 く冷却作用が十分でなかったためであると考えら れる。この点からも，もう少し流量が多い方が

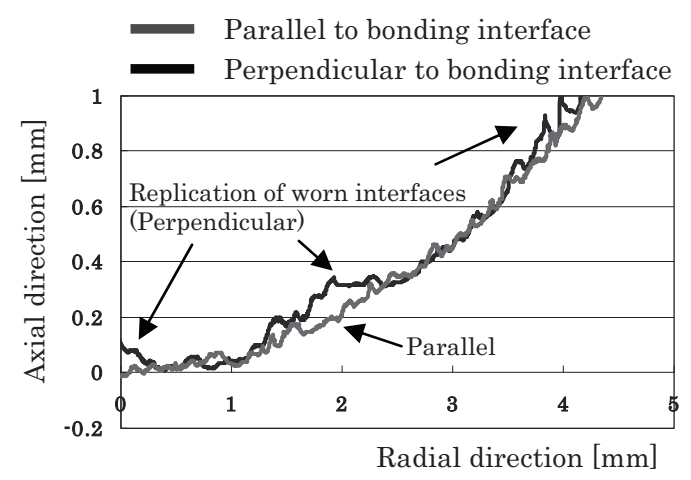

Fig.12 Influence of wear of bonding interfaces on workpiece shape
望ましいといえる。ここで，転写された稜線の高 さを測定するため, 加工底面を稜線に対して垂直 に形状測定した。Fig.12 に示寸測定結果より，垂 直に測定した形状では接合境界に沿った消耗の痕 が転写されているのがわかる，同じ図中に示した 稜線と平行に測定した場合と比べると，転写痕は 加工面の法線方向に中心軸上，および中心から $2 \mathrm{~mm}$ と $4 \mathrm{~mm}$ の位置で，ともに約 $100 \mu \mathrm{m}$ 程度突 出している。これは中仕上げ，仕上げ加工を繰返 すことで解消できると考えられる.

\section{4. まとめ}

拡散接合により微細噴流穴を形成した総形電 極素材を製作し，切削によって半球形状工具電極 を製作した。これを用いた放電加工の結果，切削 により閉塞した噴流口は, 工具電極消耗によって 開口し，加工液の供給が可能となることがわかっ た。また, 微量の加工液供給により加工を行うこ とで，ジャンプ加工と同等の加工安定性と加工精 度が得られ，ジャンプ加工より大きい加工速度が 得られた。しかし，放電により接合境界に沿って 大きな消耗が生じ，工作物面への転写により稜線 が形成された。拡散接合が不十分であったためと 考えられ，接合条件の検討が必要とされる.

\section{参考文献}

1) T. Shibayama, M. Kunieda : Diffusion Bonded EDM Electrode with Micro Holes for Jetting Dielectric Liquid, Annals of the CIRP, Vol.55, No.1, (2006), pp.171-174.

2) Kunieda, M., Katoh, R., Mori, Y. : Rapid Prototyping by Selective Electrodeposition Using Electrolyte Jet, Annals of the CIRP, Vol.47, No.1, (1998), pp161-164. 